KATARZYNA KURAS

Uniwersytet Jagielloński

iD ORCID ID: 0000-0002-6198-7131
WŁADZA I POLITYKA

W CZASACH NOWOŻYTNYCH

DYPLOMACJA I SPRAWY WEWNĘTRZNE

\title{
Dyplomacja Delfiny \\ Maria Józefa Saska wobec polityki francuskiej w polowie XVIII wieku
}

\author{
Dauphine diplomacy \\ Marie-Josèphe of Saxony towards French policy in the mid- $18^{\text {th }}$ century
}

U

rodzona 4 listopada 1731 r. Maria Józefa Karolina Eleonora Franciszka Ksawera była ósmym dzieckiem z czternaściorga, które przyszły na świat w małżeństwie elektora saskiego i króla polskiego Augusta III Wettyna i Marii Józefy z Habsburgów. Dzieciństwo spędziła w otoczeniu zżytej ze sobą i serdecznej rodziny (w gronie familijnym nazywano ją „Pepa”), która spędzała wolny czas m.in. grywając

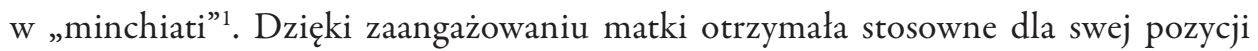
wykształcenie, posługiwała się m.in. językiem francuskim oraz łaciną ${ }^{2}$. W roku 1747, gdy miała 15 lat, została dzięki pośrednictwu wuja Maurycego Saskiego - naturalnego syna Augusta II Mocnego - wydana za mąż za świeżo owdowiałego syna Ludwika XV i Marii Leszczyńskiej, delfina Ludwika Ferdynanda ${ }^{3}$. Początki pożycia tej pary były niełatwe; delfin opłakiwał swą niedawną zmarłą małżonkę, infantkę hiszpańską Marię Teresę i został przymuszony do kolejnego związku ze względu na konieczność przedłużenia dynastii Burbonów. Jego kolejne małżeństwo miało przede wszystkim aspekt polityczny; decydując się na zbliżenie z Saksonią, dyplomaci francuscy zacierali złe wrażenie, które wywarła rywalizacja między tymi państwami w okresie wojny o sukcesję austriacką, oraz kontynuowali strategię tworzenia francuskiej strefy wpływów

\footnotetext{
${ }^{1}$ Maria Józefa do Ksawerego Saskiego, Warszawa, 1 X 1746, BPP, rkps 92, s. 405.

2 J. Staszewski, August III Sas, Wrocław 1989, s. 181.

${ }_{3}$ Zdaniem Staszewskiego małżeństwo to było dziełem Stanisława Leszczyńskiego, jest to jednak mało prawdopodobne, biorąc pod uwagę dość słabą pozycję ex-króla Polski wśród decydentów rezydujących w Wersalu (ibidem, s. 214).
} 
w Europie Północnej i Środkowej. Dzięki subtelnej i eleganckiej polityce młoda delfina szybko zaskarbiła sobie sympatię królowej Francji (a nie było to oczywiste w kontekście niedawnej rywalizacji między rodzinami Leszczyńskich i Wettynów o tron polski), a z czasem zdobyła zaufanie delfina, stając się jego prawdziwą towarzyszką życia i powierniczkąa . Choć początkowo związek był bezdzietny, a Marię Józefę obarczano za to całkowitą odpowiedzialnością, z czasem się to zmieniło, a para doczekała się ośmiorga potomków. Z tego grona troje dzieci zmarło, zaś trzech synów było kolejnymi królami Francji - Ludwik XVI, Ludwik XVIII i Karol X, a dwie córki - Klotylda i Elżbieta - przeszły do historii w opinii świętości's. Delfina osobiście pielęgnowała swego męża w trakcie choroby oraz agonii i od niego prawdopodobnie zaraziła się gruźlicą. Zmarła 13 marca 1767 r. w wieku 36 lat.

Życie - łączącej swą osobą drezdeńskie i paryskie środowisko dworskie - delfiny było dotychczas kilkakrotnie przedmiotem monograficznej uwagi historyków. W 1875 r. jej kompleksową biografię opublikowała Émilie Regnault. Zebrała ona podstawową faktografię związaną z życiem Marii Józefy, bazując głównie na pamiętnikach z epoki oraz korespondencji przechowywanej w archiwach we Francji ${ }^{6}$. $\mathrm{O}$ wiele ambitniejsze cele przyświecały tworzącemu na początku XX w. Casimirowi Stryienskiemu (1853-1912). Urodził się on w Szwajcarii jako syn powstańca z $1830 \mathrm{r}$. Aleksandra Stryjeńskiego; był nauczycielem i literatem znanym przede wszystkim jako badacz dzieł Stendhala. Odrębny nurt twórczości Stryienskiego dotyczył dworu francuskiego w czasach Ludwika XV. W roku 1904 opublikował książkę o zięciu króla Francji, Filipie księciu Parmy, a sześć lat później pracę dedykowaną życiu i działalności córek Ludwika XV i Marii Leszczyńskiej . Sporo uwagi poświęcił też samej delfinie. W 1901 r. opublikował artykuł Le secret de la Dauphine, a rok później biografię Marii Józefy8. W tytule książki znalazła się informacja, że jest to opowieść o matce trzech ostatnich Burbonów oparta na archiwaliach saskich oraz francuskich.

Koncepcja „sekretu delfiny”, którą do historiografii wprowadził Stryienski i która została ochoczo podjęta przez późniejszych biografów, m.in. Anne-Marie Gasztowtt ${ }^{9}$ oraz Ivonne Brunel ${ }^{10}$, dotyczy aktywności podejmowanej przez Marię Józefę w latach

${ }^{4}$ Słynną anegdotę, w jaki sposób Maria Józefa zaskarbiła sobie sympatię królowej, przytacza C. Stryienski, La mère des trois derniers Bourbons. Marie-Josèphe de Saxe, et la cour de Louis XV, Paris 1902, s. 70.

5 K. Malettke, Die Bourbonen, Stuttgart 2008, s. 53.

${ }^{6}$ É. Regnault, La dauphine Marie-Josephe de Saxe, mère de Louis XVI, Paris-Lyon 1875.

7 C. Stryienski, Mesdames de France, filles de Louis XV, Paris 1911; idem, Le gendre de Louis XV, don Philippe, infant d'Espagne et duc de Parme, Paris 1904.

8 C. Stryienski, Le Secret de la Dauphine (1756-1761), „Revue des Études Historiques” 1901, t. III, s. $193-207$.

9 A.-M. Gasztowtt, Le secret de la Dauphine, [Paris] 1956.

10 Y. Brunel, La Mère de Louis XVI: Marie-Josèphe de Saxe, Dauphine de France, Paris 1960, s. 82-83. Autorka dość sceptycznie traktuje zaangażowanie delfiny w sprawy sekretu, ale nie kwestionuje 
1756-1761 na rzecz wprowadzenia na tron polski swego brata, Franciszka Ksawerego ${ }^{11}$. Delfina wyłamywała się w ten sposób z polityki rodzinnej Wettynów, którzy konsekwentnie dążyli do zaakcentowania pozycji starszego z braci, Fryderyka Krystiana ${ }^{12}$. Celem jej działań było doprowadzenie do abdykacji Augusta III, koniecznie w sprzyjającej konstelacji dyplomatycznej, a następnie skłonienie Polaków w czasie wolnej elekcji do wybrania na tron jego syna, księcia Ksawerego ${ }^{13}$. Marią Józefą powodowały przede wszystkim względy osobiste; Ksawery był jej ukochanym bratem, delfina z niepokojem spoglądała na jego swoiste „bezrobocie” i „brak perspektyw”, które stały się udziałem księcia w czasie wojny siedmioletniej. Familiarnie nazywała go "Janem bez Ziemi” i była gotowa zrobić wiele, by to zmienić ${ }^{14}$. Tę tylko pozornie prostą układankę spinał swą osobą awanturnik, Marie-Antoine Bouët wicehrabia de Martange (tytuł i nazwisko zapewne sam sobie wymyślił) - Francuz z pochodzenia, eks-ksiądz i wojskowy związany z dworem drezdeńskim i upatrujący w promowaniu sprawy Ksawerego w europejskich stolicach szansy na podniesienie swej pozycji ${ }^{15}$. Martange od $1756 \mathrm{r}$. brał udział w działaniach wojny siedmioletniej; pozostawał w kręgu Ksawerego Saskiego, którego interesy nieoficjalnie reprezentował w trakcie swego pobytu w Wersalu. Martange nie był zawodowym dyplomatą, ale nie można mu odmówić pewnej zręczności w poruszaniu się na szczytach władzy. Zdołał uzyskać dostęp do François-Joachima de Pierre’a kardynała de Bernis, kierującego francuską polityką zagraniczną w latach 1758-1759. Nie są znane szczegóły prowadzonych rozmów; być może dotyczyły one przyszłości Ksawerego Saskiego. Martange jako reprezentant księcia saskiego miał również nieograniczony dostęp do Marii Józefy, z którą prawdopodobnie konferował o przyszłości jej brata w skomplikowanej rzeczywistości wojennej.

Wizyta Martange’a w Wersalu nie była ani szczególnie wyjątkowa, ani ważna, a prowadzone rozmowy nie miały walorów oficjalnych. Cała sprawa prawdopodobnie nie ujrzałaby światła dziennego, gdyby nie nieszczęśliwy zbieg wypadków, do którego doszło po bitwie pod Minden 9 lipca 1759 r. W niewyjaśnionych okolicznościach zaginęły wówczas kufry księcia Ksawerego, które ostatecznie dostały się w ręce Anglików, a ci, wiedzeni niezawodnym instynktem, dostarczyli korespondencję na dwór saski. Dla świeżo zrodzonego i dopiero rozwijającego się pomysłu osadzenia na tronie polskim

tezy, że dała się ona przekonać do pomysłu zapewnienia korony polskiej dla Ksawerego Saskiego. Koncepcje Stryienskiego w zasadzie nie występują w: M. de Huertas, Marie-Josèphe de Saxe. Mère de nos trois derniers rois de France et de Madame Elizabeth, Paris 1995.

${ }^{11} \mathrm{Z}$ reguły używano jego drugiego imienia; tę skróconą formę wybrano również w artykule.

12 J. Staszewski, August III Sas, s. 264.

${ }_{13} \mathrm{O}$ szansach Ksawerego na koronę polską pisał J.J. Vernier, Un épisode de la vie du prince François-Xavier de Saxe, comte de Lusace, sa candidature au trône de Pologne, „Mémoire de la Société Académique de l'Aube" [Troyes] 1900, t. LXIV, s. 363-409.

${ }^{14}$ Maria Józefa do Ksawerego Saskiego, [Wersal], 30 XII 1763, BPP, rkps 92, s. 473.

15 C. Stryienski, La mère des trois derniers Bourbons, s. 258. 
księcia Ksawerego były to okoliczności fatalne; plan delfiny został zdyskredytowany i o ile w sprzyjających okolicznościach mógłby zapewne spotkać się przynajmniej z chłodnym désinteressement rządzących zajętych rozgrywką na kontynencie i w koloniach, to sytuacja, w której pojawił się na dyplomatycznym ringu, czyniła go całkowicie bezużytecznym ${ }^{16}$.

Taka interpretacja wydarzeń, wprowadzona do historiografii przez Stryienskiego, okazała się zaskakująco trwała, a „sekret delfiny” definiowany jako pokrewny wobec słynnego „sekretu króla”, z którym zresztą częściowo pokrywał się czasowo, stał się wygodnym argumentem na rzecz podkreślenia silnej pozycji, którą Maria Józefa zajmowała na dworze francuskim oraz wyjątkowego zaufania, jakim darzył ją król Ludwik XV. Celem niniejszego artykułu jest dekonstrukcja sekretu w wersji, którą wprowadził do historiografii Stryienski. Choć oparł się on na źródłach związanych z aktywnością dyplomatyczną Marii Józefy, analizując je, nie uwzględnił kontekstu prawnego oraz zwyczajowego, w którym funkcjonowała każda małżonka następcy tronu francuskiego w epoce nowożytnej. Niezbędne jest więc: ukazanie pozycji delfiny na dworze francuskim i jej możliwości działania w sferze dyplomacji; uwzględnienie skali zaangażowania Francji w politykę w Rzeczypospolitej i możliwości wsparcia aktywności Marii Józefy w kontekście oficjalnych i nieoficjalnych działań dyplomatycznych podejmowanych w tym okresie; wreszcie scharakteryzowanie perspektywy polsko-saskiej przez pryzmat zagadnienia: czy Polacy byliby w ogóle skłonni poprzeć dyplomatyczne miraże Marii Józefy i czy ona sama mogła posiadać jakąś wiedzę w tej mierze?

W ustroju Francji uosobieniem władzy był monarcha, a nie jego małżonka czy członkowie rodziny panującej. $\mathrm{O}$ ile jednak pewne rozpolitykowanie kobiet było tolerowane w odniesieniu do królowych i królowych matek, o czym świadczą XVII-wieczne casusy Marii Medycejskiej czy Anny Austriackiej, to raczej nie dopuszczano tego typu postępowania ze strony kolejnych delfin ${ }^{17}$. W realiach monarchii francuskich Burbonów każdorazowa delfina była małżonką następcy tronu i dzieliła z nim przywileje, które - choć niezwykle prestiżowe - nie miały nic wspólnego z partycypowaniem w rządzeniu państwem. Nawet lubiana i ceniona przez Ludwika XIV Maria Adelajda Sabaudzka - małżonka Ludwika Burbona diuka Burgundii - była uważana za osobę wpływową wyłącznie w nieoficjalnym wymiarze. Potrafiła umiejętnie korzystać z nieograniczonego dostępu do ucha monarchy, który jednak mógł zgadzać się z jej sugestiami lub też je dyplomatycznie odrzucać ${ }^{18}$. Działania takie były całkowicie obce pierwszej małżonce Ludwika Ferdynanda, infantce hiszpańskiej Marii Teresie. Teoretycznie delfina dysponowała pewnym organizacyjnym zapleczem. Posiadała własne służby, skupione w maison wzorowanym na analogicznej instytucji będącej do dyspozycji królowej.

\footnotetext{
16 C. Stryieński, Le Secret, s. 194-207.

17 F. Cosandey, La Reine de France. Symbole et pouvoir, Paris 2000, s. 55-82.

18 J.-F. Solnon, La Cour de France, Paris 1987, s. 354-355.
} 
Między formacjami istniały drobne różnice - delfina nie miała wielkiego jałmużnika, kanclerza, maîtres des requêtes oraz pewnej liczby urzędników rady, którzy pozostawali na służbie każdorazowej monarchini ${ }^{19}$. Ów maison delfina otrzymała w momencie przybycia do Wersalu; jego skład został ułożony z uwzględnieniem interesów lokalnych koterii, a nie preferencji małżonki następcy tronu. Damą honorową została Marie-Angélique Frémyn diuszesa de Brancas, szatną Diane-Adélaïde de Mailly diuszesa de Lauraguais (siostra byłej faworyty Ludwika XV), zaś kawalerem honorowym Philippe-Charles markiz de La Fare, marszałek Francji ${ }^{20}$. Maison odpowiadało za realizację codziennych potrzeb delfiny; nie był to jednak twór o politycznym zacięciu, którego członkowie intensywnie angażowaliby się w starcia między koteriami czy dążyli do wzmocnienia pozycji małżonki następcy tronu.

Maria Józefa nigdy nie została królową Francji. Jako delfina spędziła na dworze w Wersalu 20 lat. Jej pozycja była ograniczona przez obowiązujące prawo oraz zwyczaje. Dodatkowo trzeba wziąć pod uwagę ewolucję jej nieformalnej pozycji na dworze. Gdy przybyła do Wersalu w 1747 r. została powitana bez entuzjazmu. Nawet spowinowacony z wieloma rodzinami niemieckimi Emmanuel diuk de Crö̈-Solre był pełen rezerwy; doceniał naturalną urodę Marii Józefy, ale też znajdował pewne jej potencjalne mankamenty ${ }^{21}$. Kurtuazyjny i dyskretny Charles Philippe d'Albert diuk de Luynes zauważył, że jest ona dość urodziwa, ale nie za dobrze mówi po francusku, w dodatku jej entuzjazm, chęć przypodobania się wszystkim i nieznajomość realiów życia w Wersalu nie robią najlepszego wrażenia ${ }^{22}$. Pozycja delfiny umocniła się, gdy na świecie pojawiły się pierwsze dzieci, a zwłaszcza urodzony w 1751 r. następca tronu Ludwik, książę Burgundii (zmarł w wieku 10 lat) ${ }^{23}$, a następnie jego bracia: żyjący tylko rok Ludwik Ksawery, Ludwik August, książę de Berry (późniejszy Ludwik XVI), Ludwik Stanisław, hrabia Prowansji, oraz Karol Filip, hrabia Artois. O ile więc pozycja delfiny w strukturach dworu pozostała niezmienna - uczestniczyła we wszelkich uroczystościach, udzielała audiencji - to jej status rodzinny uległ wyraźnemu wzmocnieniu; Maria Józefa była matką następców tronu. Jej wizerunek na dworze nie uległ radykalnej przemianie; delfina raczej nie należała do ludzi, którzy potrafią podobać się wszystkim i zaskarbiają powszechną sympatię. Dufort de Cheverny pisał, że była osobą

${ }^{19}$ J.-N. Guyot, P.-A. Merlin, Traité des droits, fonctions, franchises, exemptions, prérogatives et privilèges annexés en France à chaque Dignité, à chaque Office et à chaque État, soit Civil, soit Militaire, soit Ecclésiastique, t. II, Paris 1786, s. 305-306.

${ }^{20}$ Pełny skład maison delfiny z 1749 r. można znaleźć w: L'État de la France, t. II, Paris 1749, s. 351-372.

${ }^{21}$ Journal inédit du duc de Crö̈, éd. V ${ }^{\text {te }}$ de Grouchy, P. Cottin, t. I, Paris 1906, s. 77.

${ }^{22}$ Mémoires du duc de Luynes sur la cour de Louis XV (1735-1758), t. VIII, éd. L.É. Dussieux, E. Soulié, Paris 1862, s. 94, 100.

${ }^{23}$ Jego śmierć zmieniła delfinę; w jej kontekście pisała o rezygnacji i oczekiwania na łaskę Bożą. Por. Maria Józefa do Ksawerego Saskiego, [Wersal], 7 III 1761 r., BPP, rkps 92, s. 413. 
bardzo zazdrosną, trudną w kontaktach ze służbą i w efekcie nie była lubiana ${ }^{24}$. Diuk de Luynes zaznaczał, że zyskiwała przy bliższym poznaniu, ale nawet on nie potrafił wskazać zbyt wielu konkretów na jej obronęe ${ }^{25}$. To cechy jej charakteru miały w opinii pamiętnikarzy zadecydować o zbliżeniu z siostrami męża, których pasje - w tym miłość do muzyki - i styl życia daleki od blasku Wersalu Maria Józefa chętnie zaakceptowała, oddalając się zarazem od stylistyki epoki w wydaniu Jeanne-Antoinette Poisson markizy de Pompadour ${ }^{26}$.

Delfina w ciągu pierwszych lat spędzonych w Wersalu przeszła praktyczny kurs, dzięki któremu rozumiała swą pozycję i obowiązki w realiach układów dworskich i struktur władzy. Emocjonalne związki z Saksonią pozostały w jej przypadku bardzo silne - Maria Józefa szczerze ubolewała nad losem swojej rodziny w czasie wojny siedmioletniej. Deklarowała, że stara się być dobrą Francuzką i jednocześnie dobrą Saksonką ${ }^{27}$. Zarazem rodowe sympatie stopniowo ustępowały miejsca rzeczowej ocenie sytuacji politycznej oraz familijnej. Być może pewnym przełomem w rozwoju intelektualnym delfiny była klęska jej iluzorycznego sekretu. Dwa lata po niefortunnych wydarzeniach bardzo racjonalnie oceniała zarówno swą pozycję, jak i to, co działo się na arenie międzynarodowej. Współczuła rezydującemu w Warszawie ojcu, przypuszczała, że czuje się opuszczony przez Francję, ale zarazem pytała: „kim wreszcie jestem? czy sprzeciwianie się zawarciu pokoju jest moim zadaniem?"28. W efekcie niefortunnych wydarzeń zaaranżowanych przez Martange’a Maria Józefa otrzymała cenną wiedzę na temat układów w pałacu królewskim i swych możliwości. Zrozumiała, że są bardzo ograniczone i powinna dostosowywać skalę podejmowanych przedsięwzięć do swej pozycji, uważnie podążając ścieżką wyznaczoną przez politykę oraz nieformalne układy. W rezultacie w 1761 r. zadanie promowania na dworze pułkownika Sohremberga uważała za naturalne z racji interesów kraju, z którego się wywodziła, jednak nie obiecywała w tej sytuacji nic poza protegowaniem go u panny de Choiseul ${ }^{29}$. Delfina podkreślała, że nic więcej nie może dla niego zrobić3 ${ }^{30}$. Klęska iluzorycznego sekretu w 1759 r. zniweczyła wszelkie nadzieje, które ktokolwiek w Wersalu mógł wiązać z jej osobą. Nie znaczy to, że Maria Józefa przestała interesować się polityką międzynarodową. Delfina

${ }^{24}$ J.-N. Dufort de Cheverny, Mémoires sur les regnes de Louis XV et Louis XVI et sur la révolution, éd. R. de Crévecoeux, t. I, Paris 1886, s. 101. Inne opinie na temat delfiny na dworze: W.R. Newton, La Petite Cour: Services et serviteurs à la Cour de Versailles au XVIIIe siècle, Paris 2006, s. 333.

${ }^{25}$ Mémoires du duc de Luynes, t. X, Paris 1862, s. 423.

${ }^{26}$ F. Solnon, La Cour, s. 484, 515.

${ }^{27}$ Maria Józefa do Fontenaya, [b.m.], 15 VII 1758, AA, EE 1508, [bez paginacji].

28 „Que suis-je du reste, m’opposer à la paix cela est-il en mon pouvoir?” (tłum. własne). Maria Józefa do Ksawerego Saskiego, [Wersal], 7 III 1761, BPP, rkps 92, s. 413.

${ }^{29}$ Nie sposób jednoznacznie zidentyfikować tej osoby; zapewne chodzi o którąś z członkiń klanu Choiseul związaną z diukiem de Choiseul-Stainville, ministrem Ludwika XV w latach 1758-1770.

${ }^{30}$ Maria Józefa do Ksawerego Saskiego, Marly, 9 VI 1761, BPP, rkps 92, s. 422. 
uważnie śledziła zmiany politycznych konstelacji, wypatrując wszelkich informacji, które wiązały się z pozycją jej brata. W roku 1760 z ulgą obserwowała jego zbliżenie z Filipem księciem Parmy, zięciem Ludwika XV, które z jej punktu widzenia było tożsame przede wszystkim z bezpieczeństwem Ksawerego ${ }^{31}$. Maria Józefa nauczyła się jednak dystansu do dyplomatycznych gier, które stale ją otaczały, i nie pozwalała sobie po $1761 \mathrm{r}$. na jakiekolwiek niepotrzebne czy ryzykowne kroki.

Rekonstrukcja „sekretu” w wersji Stryienskiego jest mało prawdopodobna nie tylko ze względu na faktyczną pozycję Marii Józefy w strukturach władzy, ale i z punktu widzenia geopolityki z połowy XVIII w. oraz rzeczywistego zaangażowania Francji w Europie Północnej i Środkowej. Działania Marii Józefy w sferze dyplomatycznej nie miałyby sensu bez wsparcia króla Ludwika XV, przychylności któregoś z jego ministrów bądź faworyty, madame de Pompadour. W przeciwnym razie należało by je określić mianem intryganctwa o wątpliwych walorach praktycznych. Zaangażowanie Francji w Europie Środkowo-Wschodniej pozostawało od lat wyłącznie teoretyczne. Francuzi co prawda próbowali montować coś na kształt stronnictwa w Rzeczypospolitej, ale czynili to na tyle nieefektywnie, ograniczając ewentualne zaangażowanie finansowe, że chyba nikt - może z wyjątkiem hetmana Jana Klemensa Branickiego - na poważnie nie liczył się z ich wpływami w latach pięćdziesiątych wieku XVIII ${ }^{32}$. Dodatkowo król miał swój własny sekret i podwójną dyplomację obsadzoną w zdefiniowanych rolach i opłacaną z prywatnej szkatuły, której celem było ulokowanie na tronie polskim Louisa-François de Bourbon księcia de Conti i faktyczne wzmocnienie pozycji Francji w tym rejonie ${ }^{33}$. Sekret króla i sekret delfiny łączyły rejestry geograficzne i ogólne cele, czyli chęć osadzenia na tronie polskim własnego kandydata; jego personalia obie strony widziały jednak całkowicie odmiennie, bo też oba sekrety miały różne założenia strategiczne. Nawet jeśli zgodzimy się ze stwierdzeniem Stryienskiego, że z korespondencji sekretnej Ludwika XV i Jeana-Pierre’a Terciera wynika, iż delfina wywierała przed 1759 r. znaczny wpływ na teścia, to nie ma jakichkolwiek przesłanek pozwalających sądzić, że wpływ ten obejmował politykę wschodnią króla ${ }^{34}$. Co prawda władca francuski - zapewne zainspirowany rozmowami z Marią Józefą - rozważał wady i zalety poszczególnych książąt saskich; niemniej, gdyby jego refleksja nie ograniczała się do teoretyzowania na ten temat, to na poważnie rozważyłby sprawę małżeństwa Ksawerego

${ }^{31}$ Maria Józefa do Ksawerego Saskiego, [Wersal], 27 VI 1760, BPP, rkps 92, s. 409.

${ }^{32} \mathrm{Na}$ temat kondycji tzw. partii francuskiej u schyłku lat czterdziestych XVIII w. pisze K. Kuras, „Ludzie, którzy moga być użyteczni". Profrancuskie elity Rzeczypospolitej w 1748 r., [w:] Spoteczeństwo staropolskie. Seria nowa, t. V (Spoteczeństwo a elity), red. I. Dacka-Górzyńska, A. Karpiński, Warszawa 2018, s. 183-195. O partii francuskiej i jej wsparciu przez Francję: E. Rostworowski, Francja, Polska i Podlaski Wersal, [w:] Polska czasów saskich, red. M. Wrzosek, Białystok 1986, s. 31-57.

33 G. Perrault, Polskie szaleństwo, Warszawa 1997.

${ }^{34}$ C. Stryienski, Le Secret, s. 196. 
z jedną ze swych córek ${ }^{35}$. Mariaż ten był silnie promowany przez delfinę, jego efektem mogło być wyraźne opowiedzenie się Francji po stronie kandydatury saskiej i w dłuższej perspektywie wzmocnienie pozycji w regionie. Byłoby to jednak całkowicie niezgodne z oficjalną polityką Królestwa, wszak w traktacie z Austrią podpisanym w 1758 r. Ludwik XV deklarował, że nie będzie angażował się w jakiekolwiek działania, które mogłyby zakłócić elekcję króla polskiego ${ }^{36}$.

Istotna w tym kontekście była również pozycja delfiny w układach rządzących Wersalem. W momencie, gdy wkraczała do pałacu wszystkie drogi formalnie były przed nią otwarte. Dysponowała carte blanche u faworyty króla markizy de Pompadour, bo dzięki jej wsparciu został zaaranżowany drugi mariaż delfina ${ }^{37}$. Znajdowała się zarazem blisko rodziny królewskiej, do której została włączona. To drugie środowisko okazało się jej bliższe. W efekcie Maria Józefa postawiła na wsparcie inicjatyw męża, królowej Marii Leszczyńskiej oraz monarszych córek - wszyscy oni sympatyzowali z funkcjonującymi na dworze, choć dość rachitycznymi strukturami partii pobożnych (w historiografii zwana jest ona często stronnictwem dewotów) ${ }^{38}$. Nie była to grupa szczególnie wpływowa - jednoczyła ludzi religijnych (w tym duchownych związanych z dworem królewskim), konserwatystów oburzonych rewoltą parlamentów, wreszcie kontestatorów polityki Ludwika XV, niezadowolonych zarówno z podejmowanych działań, jak i grzesznego życia osobistego monarchy. W układach dworskich partia pobożnych rywalizowała z ugrupowaniem jansenistów, które dyskretnie wspierali diuk de Choiseul i markiza de Pompadour. W 1756 r. wydawało się, że partia pobożnych zyskała przewagę, jednak po zamachu Roberta-François Damiensa na fali rozbudzonej debaty politycznej i wzrostu niepopularności jezuitów jej akcje zaczęły gwałtownie spadać. Trend ten utrzymał się w latach sześćdziesiątych XVIII w. - wpływy pobożnych stały się na tyle iluzoryczne, że nie byli w stanie powstrzymać wypędzenia jezuitów w roku $1764^{39}$.

${ }^{35}$ C. Stryienski, La mère des trois derniers Bourbons, s. 94, 99. Trudno uznać za przekonujące tlumaczenie autora, że król nie zdecydował się na mariaż francusko-saski, by nie robić przykrości synowej, w przeciwnym razie wybrałby nie tego kandydata, którego ona sama promowała.

${ }^{36}$ Traktat ten był skutkiem odwrócenia aliansów z roku 1756. Został podpisany 30 XII 1758 r. w Wersalu. Francja i Austria opowiadały się za wolną elekcją, zastrzegając, że chętnie widziałyby na tronie polskim reprezentanta dynastii saskiej. Ch.G. de Koch, Abrégé de l' histoire des traités de paix entre les puissances de l'Europe depuis la paix de Westphalie, Bruxelles 1837, t. I, s. 77-78.

37 Wsparcie madame de Pompadour było wątpliwe - co prawda delfina podejmowała pewne formalne kroki mające na celu zyskanie jej przychylności, ale nie wyszły one poza poziom dworskiej kurtuazji. Por. C. Stryienski, La mère des trois derniers Bourbons, s. 79-80.

38 A. Ravel-Cordonnier, Vie et mort du «parti dévot» dans le Royaume de France (XVIIe-XVIIIe siècles), [w:] Naissance et mort des partis politiques. Genèse, cycle de vie et déclin des partis politiques, [materiały konferencyjne z 2009 r.].

39 Ibidem, s. 11. 
Układ sił pomiędzy fakcjami na dworze okazał się wyjątkowo niefortunny dla wszelkich ewentualnych samodzielnych inicjatyw delfiny. Jeśli więc wsparcie jej działań u schyłku lat pięćdziesiątych XVIII w. ze strony króla bądź któregoś z ludzi liczących się w ówczesnych układach władzy było iluzoryczne, to co wydarzyło się w Wersalu, gdy korespondencja Ksawerego została przekazana przez Anglików Augustowi III? Nie chodziło o same listy księcia saskiego oraz Marii Józefy, ale raczej o różnego rodzaju memoriały przygotowane przez Martange’a, w których kreślił śmiałe wizje abdykacji króla polskiego i doniosłych skutków tego wydarzenia dla przyszłości dynastii i Europy. Korespondencja Marii Józefy, niestety w znacznej mierze niedatowana, pozwala tylko częściowo zrekonstruować strategię, którą wybrała w obliczu tak niefortunnych okoliczności. Sprawa szybko zatoczyła dość szerokie kręgi; rozmawiano o niej zarówno w Wersalu, jak i w Dreźnie. Delfina działała ostrożnie, podkreślając, że w tych smutnych okolicznościach „nie można przedsięwziąć żadnych środków”0. Kontaktowała się przede wszystkim z oficjalnym wysłannikiem dworu saskiego w Paryżu generałem Gaspardem-François de Fontenayem (poseł od 1757 r.), którego darzyła zaufaniem, i starała się za jego pośrednictwem wysondować stanowisko dworu saskiego, głównie Augusta III i jego pierwszego ministra Henryka Brühla. Przygotowywała list do ojca, którego treść konsultowała z Fontenayem, a zarazem niepokoiła ją silna pozycja, którą zajmowała na saskim dworze córka ministra i żona polskiego marszałka nadwornego koronnego Amelia Mniszchowa. To ona - w opinii delfiny - należała do stronnictwa, któremu zależało na rozpowszechnieniu sprawy przejętej korespondencji ${ }^{41}$. W Wersalu ograniczyła się do rozmów z kardynałem de Bernis, który demonstrował wielkie wzburzenie w obliczu zaistniałej sytuacji ${ }^{42}$. Delfina z ulgą przyjęła odjazd Martange'a $\mathrm{z}$ Wersalu; w oficjalnych rozmowach z kardynałem i Fontenayem traktowała go chłodno, dystansując się również od pomysłów wiążących się z kandydaturą brata do tronu polskiego ${ }^{43}$. Wszelkie swe wcześniejsze inicjatywy określała konsekwentnie mianem głupoty, którą tylko częściowo usprawiedliwiał fakt, że memoriały Martange’a były bardzo przekonujące i dobrze zredagowane ${ }^{44}$.

W późniejszych latach - zwłaszcza w okresie, gdy francuską polityką zagraniczną kierował Choiseul - Maria Józefa wypowiadała się na ten temat bardzo lapidarnie.

${ }^{40}$ Maria Józefa do Fontenaya, [b.m. i d.], AA, EE 1507, [bez paginacji].

${ }^{41}$ J.G. Flammermont, Les correspondances des agents diplomatiques etrangers en France avant la revolution, Paris 1896, s. 176; Maria Józefa do G.-F. de Fontenaya, [b.m.], 23 [? 1759?], AA, EE 1508 [bez paginacji].

${ }^{42}$ Maria Józefa do G.-F. de Fontenaya, [b.m. i d.], AA, EE 1507, [bez paginacji].

${ }^{43}$ Maria Józefa do G.-F. de Fontenaya, [b.m. i d.], AA, EE 1508, [bez paginacji]. Ostre słowa delfiny wobec Martange’a były wyjątkowe w kontekście tych okoliczności; z reguły wypowiadała się na temat wicehrabiego $\mathrm{z}$ wielkim entuzjazmem.

${ }^{44}$ Maria Józefa do G.-F. de Fontenaya, [b.m.], 29? [1759?], AA, EE 1509, [bez paginacji]. 
W 1761 r. wspominała tylko, że persony źle nastawione wobec księcia saskiego mogą próbować wykorzystywać rozkazy, które przesłał siostrze w sprawie kasetki, a których ona sama nie mogła wypełnić. Być może chodziło o „deux pièces”, które przekazał jej brat i których realizacja została zablokowana przez Bernisa ${ }^{45}$. Zapewne czynił to za wiedzą monarchy, niezbyt do tej pory zorientowanego w rozmachu akcji podejmowanych przez małżonkę swego syna. Kontrakcję podjął również delfin, ostrzegając Marię Józefę, że jej zaangażowanie w tego typu „szaleństwa” (folies) nie przyniesie niczego dobrego $^{46}$. Zdaje się, że delfinie zależało na odzyskaniu kasetki; podejmowała dyskretne zabiegi, by ów cel osiągnąć, zarazem deklarowała, że jej korespondencja z bratem może zostać wydrukowana, by przeciąć wszelkie spekulacje i podejrzenia ${ }^{47}$.

Okoliczności tych wydarzeń nie powinny być zarazem przesadnie oceniane w kontekście różnorodnych spraw, wokół których koncentrowała się uwaga decydentów Wersalu. Korespondencja delfiny, zapewne mniej dyskredytująca ją samą niż przypuszczał Stryienski, stanowiła z ich punktu widzenia zaledwie margines rzeczy ważnych. Jak pisał Władysław Konopczyński: „Elżbieta i Marya Teresa nie myślały kłócić się z Francją i Saksonią o błahostki [chodziło o memoriał Martange'a - K.K.] - ku uciesze Pitta i Fryderyka II”æ\$8. Małżonka Ludwika Ferdynanda wykazała się co prawda pewną nadmierną samodzielnością, ale nie była ona na tyle duża, by przedsięwziąć konkretne kroki dyscyplinujące ją (jej rozmowy z mężem trudno zaliczyć do tej kategorii, wszak odbywały się w przestrzeni prywatnej). Rzekomy sekret nie stał się nawet powodem do trwałego oddalenia niefortunnego pośrednika, Martange’a, który jeszcze w 1763 r. odgrywał istotną rolę w kontaktach Marii Józefy z Ksawerym Saskim ${ }^{49}$. Delfina, być może w ramach wynagrodzenia chwilowego chłodu, wystarała się dla niego o krzyż św. Ludwika oraz o przydzielenie apartamentu w budynkach przylegających do Wersalu ${ }^{50}$.

Co do trzeciej perspektywy - polsko-saskiej - to wydaje się ona szczególnie ważna w kontekście tych rozważań. Delfina była córką polskiego króla i realia polityczne regionu nie były jej obce. Nie chodzi tylko o jej wykształcenie, bo raczej nie obejmowało materii prawa międzynarodowego, ale o pewne obycie, którym mogła się legitymować

${ }^{45}$ Maria Józefa do G.-F. de Fontenaya, [b.m. i d.], AA, EE 1508, [bez paginacji].

${ }^{46}$ Maria Józefa do Ksawerego Saskiego, Marly, 9 VI 1761, BPP, rkps 92, s. 421-422.

${ }^{47}$ Maria Józefa do Ksawerego Saskiego, [Wersal], 8 XI 1761, BPP, rkps 92, s. 425-427; C. Stryienski, La mère des trois derniers Bourbons, s. 267.

48 W. Konopczyński (rec.), Massé Daniel, Un candidat au thrône de Pologne, 1759-1764, Revue de Paris 1905, octobre, 617-631; Nieudawszajastia kandidatura na polskij prestsot 1759-64, Russkaja Starina 1905, IV , 476-486, „Kwartalnik Historyczny” 1908, R. XXII, s. 460-461.

49 Maria Józefa do Ksawerego Saskiego, [Wersal], 24 XII 1763, BPP, rkps 92, s. 470; Maria Józefa do G.-F. de Fontenaya, [b.m. i d.], AA, EE 1507, [bez paginacji].

${ }^{50}$ Maria Józefa do G.-F. de Fontaneya, [b.m. i d.], AA, EE 1509, [bez paginacji]. 
jako córka Augusta III. Wraz z rodziną często przebywała w Rzeczypospolitej i podróżowała po kraju. Grywała w „minchiati” nie tylko z matką i siostrami, ale i z nuncjuszem $^{51}$. W stolicy Polski spędzała czas w grudniu 1740 r., zapewne więc była obecna podczas obrad sejmowych ${ }^{52}$. W roku 1744 towarzyszyła ojcu w czasie jego podróży na feralny sejm grodzieński, który został zniweczony, mimo intensywnego kształtowania opinii szlacheckiej i nadziei na koncyliację w celu reformy państwa ${ }^{53}$. W tym samym roku królewska córka składała wizytę na Jasnej Górze ${ }^{54}$. W roku 1746 przebywała w Warszawie w przeddzień rozpoczęcia obrad sejmowych, które prawdopodobnie obserwowała z pozycji osoby bliskiej centrum wydarzeńs5. Po 1747 r. utrzymywała kontakty z Polakami i przyjmowała ich wizyty w Wersalu. Praktyczna edukacja, którą w ten sposób otrzymywała, choć trudna do precyzyjnego określenia, musiała obejmować m.in. przyczyny kryzysu Rzeczypospolitej oraz politycznego impasu, w którym znalazł się kraj pod rządami Wettynów. Co prawda opuściła Saksonię jako młoda dziewczyna, ale nie sposób uwierzyć, by jej wykształcenie oraz pewne naturalne polityczne obycie pozwalały choćby przypuszczać, że plan zakreślony przez Martange’a - zasadzający się na abdykacji Augusta III i elekcji Ksawerego - mogłaby uznać za mający szansę powodzenia. Hipotezę tę potwierdza również zachowanie delfiny w obliczu bezkrólewia w Rzeczypospolitej po śmierci Augusta III i zbliżających się targów elekcyjnych. Maria Józefa bacznie śledziła sytuację w tej części Europy zapewne powodowana permanentną troską o interesy brata. Już w listopadzie 1763 r. dysponowała informacjami, że o koronie myśli raczej nie Adam Kazimierz Czartoryski, ale jego ojciec August Aleksander ${ }^{56}$. Wiedziała też, że jest dwóch innych kandydatów - książę Anhalt (?) oraz stolnik litewski Stanisław Poniatowski. Pierwszy brany był pod uwagę ze względu na zasługi brata, drugi zaś mógł liczyć na wsparcie carycy Katarzyny II, której był dawnym faworytem ${ }^{57}$. Delfina musiała mieć swoich zaufanych informatorów na terenie Rzeczypospolitej; od śmierci jej ojca minęły niecałe dwa miesiące (August III zmarł 5 października 1763 r.), a do niej błyskawicznie trafiały wiadomości i plotki o przyszłych elekcyjnych targach. W grudniu była na bieżąco w kwestii inicjatyw marszałka nadwornego Jerzego Augusta Mniszcha, jego żony Amelii oraz synów Brühla mających na celu zmniejszenie szans elektora saskiego na polską koronę.

51 Maria Józefa do Ksawerego Saskiego, Warszawa, 1 X 1746, BPP, rkps 92, s. 405.

52 Maria Józefa do Ksawerego Saskiego, Warszawa, 3 XII 1740, ibidem, s. 397-399.

53 Maria Józefa do Ksawerego Saskiego, Grodno, 29 X 1744, ibidem, s. 401.

54 J. Bajer, Une dauphine d'esprit polonais à la cour de Versailles, „Annales - Centre Scientifique de l'Académie Polonaise des Sciences à Paris" 2015, no. 17, s. 107.

55 Maria Józefa do Ksawerego Saskiego, Warszawa, 1 X 1746, BPP, rkps 92, s. 405.

${ }^{56}$ Tę część listu błędnie odczytał Stryienski, który w miejscu ojca (père) Adama K. Czartoryskiego umieścił brata (frère). C. Stryienski, La mère des trois derniers Bourbons, s. 304.

57 Maria Józefa do Ksawerego Saskiego, [Wersal], 27 XI 1763, BPP, rkps 92, s. 457. 
Delfina była sceptyczna co do możliwości powodzenia ich planu, co tylko dowodziło jej wyczucia w odniesieniu do spraw dziejących się nad Wistą ${ }^{58}$. Rozpatrując szanse ulubionego brata w elekcyjnym wyścigu, realistycznie zaznaczała, że nie może mu udzielić żadnej pomocy w walce o polską koronę, choć oczywiście chciałaby, by to on okazał się zwycięzcą tej rywalizacji ${ }^{59}$. Ostatecznie rekomendowała mu wsparcie kandydatury brata, elektora saskiego, i tylko ten plan uważała za możliwy do zrealizowania w obliczu rosyjskiej przewagi w regionie oraz iluzoryczności ewentualnej pomocy ze strony Francji ${ }^{60}$. W dniu 21 września 1764 r. spodziewała się w Wersalu oficjalnych wieści o elekcji stolnika litewskiego; prywatni informatorzy donieśli jej o wynikach wyborów nieco wcześniej, bo 14 września. Rezultat elekcji Maria Józefa postrzegała w kategoriach woli Bożej; po wrześniu 1764 r. zachowała wyłącznie dyplomatyczną czujność w odniesieniu do sytuacji w regionie ${ }^{61}$.

Biorąc pod uwagę scharakteryzowane powyżej założenia, uważam, że sekret delfiny Marii Józefy w rzeczywistości nie istniał, a kolejni historycy, poczynając od Stryienskiego (Régnault nie znała jeszcze listów wydanych w 1898 r.), dali się uwieść korespondencji Martange’a, w której nakreślił ambitne plany mające pomóc mu w zrobieniu kariery - czy to na dworze wersalskim czy drezdeńskim. Wiarygodność tych listów wydaje się wątpliwa; wizje, które snuł wicehrabia to bardziej domek z kart niż rzeczywiste układanki dyplomatyczne ${ }^{62}$. W memoriale przygotowanym w 1759 r. dla Ksawerego Saskiego Martange nieustannie podkreślał znaczenie księcia dla przyszłości Saksonii i Europy, najpierw kreując, a następnie podtrzymując w nim wiarę, że ma do odegrania wielką rolę. Ambitny Francuz zabiegał w rzeczywistości o swe powodzenie - wzrost pozycji brata Marii Józefy oznaczał istotne zmiany również w jego karierze. Wicehrabia z prawdziwą brawurą żonglował przyszłością Starego Kontynentu po przewidywanej już w 1760 r. klęsce Fryderyka II. Spodziewał się rozbioru pruskich posiadłości, na bazie których miała wzbogacić się Saksonia. Dla elektoratu była to zarazem szansa na uzyskanie statusu królestwa oraz przeniesienie politycznego środka ciężkości w stronę Zachodu. W opinii Martange’a oznaczać to będzie spadek zainteresowania Augusta III sprawami Rzeczypospolitej i ułatwi przekonanie zarówno jego samego, jak i Brühla do zaakceptowania pomysłu abdykacji z tronu polskiego. W tych nowych realiach

${ }^{58}$ Maria Józefa do Ksawerego Saskiego, [Wersal], 9 XII 1763, ibidem, s. 465. Realistycznie o delfinie wobec wydarzeń w Polsce pisze również C. Stryienski, La mère des trois derniers Bourbons, s. 300. Maria Józefa nie darzyła marszałkowej nadwornej sympatią i uważała, że nadmiernie miesza się do spraw politycznych. Na ten temat m.in. Maria Józefa do Fontenaya, [b.m. i d.], AA, EE 1507, [bez paginacji].

59 Maria Józefa do Ksawerego Saskiego, [Wersal], 9 X 1763, BPP, rkps 92, s. 437.

${ }^{60}$ Maria Józefa do Ksawerego Saskiego, [Wersal], 24 XII 1763, ibidem, s. 469.

${ }^{61}$ Maria Józefa do Ksawerego Saskiego, [Wersal], 21 IX 1764, ibidem, s. 497; [Wersal], 16 IX 1764, ibidem, s. 505; Fontainebleau, 6 X 1764, ibidem, s. 517.

${ }^{62}$ Bardziej przychylnie wypowiada się na temat korespondencji wicehrabiego. Por. A.W. Ward na łamach recenzji opublikowanej w „The English Historical Review” 1900, vol. XV, No. 57, s. 177-180. 
politycznych tron saski powinien przypaść najstarszemu synowi elektora, zaś tron polski Ksaweremu, co stanowiłoby dobre rozwiązanie z punktu widzenia saskiej dynastii. Dla wicehrabiego tego typu kombinacja była oczywista w świetle polityki europejskich dworów; jedynym wyjątkiem od tej reguły były cele dyplomacji rosyjskiej. Nie widział też żadnych trudności ze strony Francji, która co prawda wspierała sekretnie kandydaturę księcia Contiego, ale powinna porzucić te miraże w momencie, gdy na firmamencie zabłyśnie gwiazda księcia saskiego. Wicehrabia podkreślał, że nie chodziło tu wyłącznie o pokrewieństwo księcia i delfiny. Wsparcie Ksawerego i wybudzenie z letargu Polaków leżało w interesie decydentów Królestwa Francji, zazdrośnie patrzących od lat na dominującą pozycję Rosji w regionie i otrzymujących w ten sposób szansę na zbudowanie przeciwwagi w tej części kontynentu ${ }^{63}$. W listach Martange'a pełno jest tego typu śmiałych myśli, zbudowanych na zasadzie kumulacji absurdów i sytuacji nieprawdopodobnych bądź mających niewielkie szanse na realizację. Memoriały, które wyszły spod jego pióra, stanowią dowód jego niezwykłej wyobraźni i kreatywności dyplomatycznej; trudno uwierzyć, by ktokolwiek zorientowany w realiach polityki XVIII w. traktował wynurzenia w tym duchu w sposób poważny. Politycy z epoki określali go wprost mianem ignoranta ${ }^{64}$.

Martange w swych niewiarygodnych planach przewidywał też ważne miejsce dla delfiny - miała pilotować całą sprawę w Wersalu, podejmować negocjacje z ministrami i stopniowo przejmować inicjatywę, pilnując tego, aby instrukcje dla francuskich ambasadorów w Rzeczypospolitej i w Rosji były odważne, a polityka Ludwika XV w Europie Środkowej została wyrwana z marazmu, w którym stopniowo pogrążała się w ostatnich latach $^{65}$. Delfinie Martange powierzał więc taką rolę, której ona sama zapewne nie projektowała w najbardziej optymistycznym scenariuszu. Stawała się nie tylko zwierzchniczką sekretu, ale i jego siłą napędową. Wicehrabia kreował również w ten sposób rzeczywistość śmiałą i nierealistyczną, w której lokował Marię Józefę jako brakujący i naturalny element swej dyplomatycznej układanki, która runęła po przejęciu memoriałów przez Anglików. Nie oznacza to zarazem, że sama delfina nie myślała o tronie polskim dla swego brata. Jej koncepcje raczej należałoby określić mianem „marzenia”, a nie „sekretu”, mającego niewiele wspólnego ze śmiałymi wizjami Martange’a.

Dlaczego w taki razie Casimir Stryienski, znawca literatury, dość dobrze zresztą zorientowany w źródłach rękopiśmiennych oraz memuarach z XVIII w. o dworskiej proweniencji, dokonał tak przesadnej rekonstrukcji wydarzeń? Jego tezy pojawiające

${ }^{63}$ M.-A. Bouët de Martange, Correspondance inédite du général-major de Martange aide de camp du Prince Xavier de Saxe, lieutenant général des armées (1756-1782), éd. Ch. Bréard, Paris 1898, s. 82, 99, Martange au prince Xavier de Saxe [1759]; Mémoire de Martange sur un établissement à procures au Prince Xavier, Sächsisches Hauptstaatsarchiv Dresden, 10026 Geheimes Kabinett, Nr. Loc. 03501/08.

${ }^{64}$ C. Stryienski, La mère des trois derniers Bourbons, s. 270.

${ }^{65}$ M.-A. Bouët de Martange, Correspondance inédite du général-major de Martange, s. 87. 
się w kwestii „sekretu” sprawiają wrażenie o wiele bardziej naiwnych niż myśli, które kierowały Marią Józefą w 1759 r. Przede wszystkim Stryienski, zresztą nie jako pierwszy czy jedyny, przesadnie oceniał możliwości sterowania opinią szlachecką podczas wolnych elekcji. O ile w XVI czy XVII stuleciu takie intencjonalne kierowanie polem elekcyjnym mogło mieć miejsce (klasycznym tego przykładem była elekcja Michała Korybuta Wiśniowieckiego, która została wygrana dzięki motywowi Boskiej interwencji), to wynik nieobliczalnych wyborów z XVIII w., dodatkowo skomplikowanych intensywną infiltracją państw ościennych, był z góry niezwykle trudny do przewidzenia. Trudno uwierzyć, by Stryienski nie znał historii elekcji z roku 1697, 1733 czy 1764. A mimo to, rozpatrując szanse księcia Ksawerego najpierw na poślubienie jednej z córek Ludwika XV, a następnie na sukces na polskim polu elekcyjnym po abdykacji lub zgonie Augusta III, dał się ograć dyplomatom saskim, którzy starali się przeforsować pewne postulaty w Wersalu pod pozorem zwiększenia wpływów Francji w Europie Środkowej. To oni - nie licząc się z realiami, które doskonale znali - lansowali nad Sekwaną tezę, że zięć króla francuskiego miałby oczywiste szanse na wygraną w kolejnej polskiej elekcji, a nawet rozpuszczali plotki o ewentualnej abdykacji Augusta III na rzecz syna ${ }^{66}$. Prawdopodobnie ich raportom całkowicie zawierzył Stryienski, uznając, że przyjęta w ten sposób perspektywa najlepiej wyjaśnia saskie, znamienite skądinąd dążenia do sukcesji tronu w Rzeczypospolitej (a tego, że Wettynowie o tym zamyślali, nie sposób kwestionować), a zarazem zawiera odpowiednią dozę admiracji dla pozycji Burbonów na mapie Europy, której biograf delfiny nie zamierzał w żaden sposób podważać. Efekt analizy w świetle takich założeń jest literacko interesujący, a jednocześnie niepełny. Ignorując uwarunkowania polskich elekcji w XVIII w. i szeroki kontekst międzynarodowy tych wydarzeń - wykraczający poza perspektywę saską, francuską oraz miraże dynastyczne - Stryienski czynił wszystko, aby ukazać świetność domu, z którego wywodziła się delfina i dynastii, do której weszła. W rezultacie wykreował fikcyjną rzeczywistość dyplomatyczną i stworzył sekret, który był bez znaczenia dla przyszłości Francji, Rzeczypospolitej i Saksonii, bo wiązał się z osobą, która w poważnych rokowaniach nie mogła się liczyć. Na usprawiedliwienie autora zaznaczmy tylko, że zapewne działał w dobrej wierze kierowany autentyczną fascynacją rzeczywistością Wersalu pod rządami Ludwika XV oraz sympatią dla bohaterki swych analiz, co zresztą było zgodne z duchem epoki, w której tworzył.

${ }^{66}$ C. Stryienski, La mère des trois derniers Bourbons, s. 95-97. 


\section{Abstract}

The article presents ,the secret of Dauphine of France", i.e. the actions taken by Marie-Josèphe of Saxony (1731-1767), the wife of Dauphin of France Louis Ferdinand, to bring her brother, Prince Francis Xavier de Saxony, to the Polish throne. The „secret" reconstructed in works published between 1901 and 1902 by Casimir Stryienski occupies a marginal but permanent place in the historiography literature. In the light of this analysis, which takes into account the legal and traditional position of Dauphine at the French court, the foreign policy of France in Central and Eastern Europe in the middle of the $18^{\text {th }}$ century, and the knowledge that Maria Józefa possessed on the realities of the Polish policies, it turns out that the "secret" in its current version was an exaggerated, literary construct rather than a diplomatic reality.

\section{Keywords}

„The secret of Dauphine”, Marie-Josèphe of Saxony, French diplomacy, $18^{\text {th }}$ century. 